\title{
TRAVELLING LANGUAGES: TOWARD A GEOLINGUISTIC IMAGINATION ${ }^{1}$
}

\author{
Mary Louise Pratt \\ New York University - USA
}

\section{RESUMO}

Em diálogo direto com questões voltadas para a compreensão das dimensões linguísticas presentes em torno dos realinhamentos planetários, sociais, ecológicos, econômicos, políticos e imaginários impulsionados pela globalização contemporânea, o presente artigo está focado no diálogo sobre o papel e a importância da linguagem para a definição e mesmo determinação dos processos e transformações operadas por essa globalização, principalmente, levando em consideração a necessidade de inserir a língua no centro desse debate, como importante categoria de análise para a reflexão sobre a dinâmica das transformações em curso.

PALAVRAS-CHAVE: Globalização. Migração. Geolinguística. Linguagem. Competência linguística.

Vadim Perelman's film "The House of Sand and Fog," based on the novel by Andre Dubus III, narrates a tragic confrontation between a young Anglo-American woman and an Iranian immigrant who acquires her house by goverment auction after a miscalculation of her tax liability. At a key point in the story, the distraught woman calls on the Iranian's gentle and unhappy wife to explain the situation. The viewer's hopes rise. Will the women be able to find a just solution where the men are acting by codes of violence and self-interest? The young woman describes what has happened. The wife looks on sympathetically. There's a pause. "You don't understand a thing I'm saying, do you?" The Iranian wife hands her a paper, "You write it all down. I show to my husband." The possibility of a women's solution is blo-

1 Prepared for UNESCO Seminar on "Sharing Intangible Cultural Heritage: Narratives and Representations," Oaxaca, January 2009. The material presented here was developed in lectures given at the University of California, Berkeley; Michigan State University, Kalamazoo; the University of Illinois at Chicago; the University of California at San Diego; and the Australian Academy of the Humanities, University of Melbourne. 
cked by another gendered reality: the sequestered immigrant wife trapped in monolingualism and its attendant dependency. Later another linguistic failure triggers the film's disastrous climax. The Iranians' teenage son is shot and killed when he attacks a rogue police officer who has been trying to help the young woman recover her house. His reason? The cop has mispronunced his name, calling him Ishmael instead of Esma'il. It is the last straw. ${ }^{2}$

Two things struck me about these scenes from The House of Sand and Fog: first, language, or rather linguistic difference, determined the plot; and second, this was very likely to escape the viewer's notice. The House of Sand and Fog is about immigration, its geopolitics, its transcultural improvisations, its charged, even fatal, poetics. Language and translation are at the heart of these, as they are at the heart of the dramatic events that have unfolded in the last three years in Afghanistan and the Iraq. ${ }^{3}$ The allusion to Moby Dick resonates: which is it going to be in $21^{\text {st }}$ century America? Will Ahab learn to say Esma'il, or will Esma'il accept a name change? Or will this behemoth take us all down, as it takes down the characters in Dubus's sorrowful tale.

What are the linguistic dimensions of this cluster of planetary social, ecological, economic, political and imaginary realignments that we call globalization? It can be hard to see them, in part because language is always there, always at work; it's the medium in which both the realigning and the analysis of it are going on. Language is often overlooked because the people who think about globalization are rarely trained to think about language. If you pick up one of the

2 Both these incidents take place somewhat differently in the novel, whose concern with language is even more all consuming than the film's.

3 Farsi, the language being spoken and misspoken in The House of Sand and Fog, has long been on the State Department's list of critical languages. 
dozens of anthologies on globalization, you probably won't find an entry for language in the index; you certainly won't find a chapter on language in the table of contents. Language has not been a category of analysis in the now vast literature on globalization. As a rule its force is simply overlooked in theorizations of globality, mobility, markets, and geopolitics. Yet global processes are determined by language at every turn. ${ }^{4}$ Language channels migration, trade and communications, determining who is more likely to trade with whom, who is more or less likely to migrate where, and more likely to thrive, who are able to negotiate on their own behalf, and with whom. Language is one of the main reasons this thing being called globalization tends to follow older lines of imperial expansion and diaspora, often in reverse. Argentines migrate "back" to Spain and Italy; ${ }^{5}$ Surinamese to the Netherlands, North Africans to France and Spain, South Asians and West Indians to Britain, Canada and the US, and so on. The Filipino diaspora is shaped by its effective English language education system, a product of US imperial strategy. Postcolonial as we are, imperial and diasporic histories remain in play in the new world order, and language is a big reason this is so.

Markets are linguistically structured and linguistically regulated. In transnational labor circuits, what jobs you can compete for depend on what languages you know or don't know and how well you do or don't know them. Your socioeconomic mobility can be determined by your access to language learning. Linguistic gatekeeping often operates to keep people "in their place." Many of us remember, and it may

4 This point needs some clarification. Quite a number of people who think about language think about globalization, usually under three rubrics: the disappearance of small languages, the growing need for translation and interpretation, the spread of global English. The people who think about globalization, on the other hand, almost never think about language.

5 Re Arg migration to Spain; numbers leaving after debt crisis 
still be true, when the test for bilingual teachers in California could readily be passed by people who could scarcely use Spanish at all but knew grammar and could generate forms like the imperfect subjunctive. The test was thus impossible to pass for educated native speakers who might well be completely literature but had not studied formal grammar in this way. In New York the CUNY English writing test is known in the barrio as a notorious upstream barrier keeping people from graduating and moving up in the job market. ${ }^{6}$ When the game involves requiring English without providing ways for people to learn it, the game is rigged to produce an underclass, whether or not anyone intends it. [ I have wondered whether such unconscious rigging helps explain the refusal to invest in language learning in the U.S., or even to think about language at all. If they think about language at all, people often imagine it as something like a self regulating market. Human groups it is thought will pragmatically acquire or invent the linguistic resources they need to sustain the relationships they want to have. Trade languages, known as pidgins or interlanguages, develop quickly. English has become an international lingua franca. In the U.S. despite monolingual policies, Spanish has become the de facto second language. In pueblos of Northern Jalisco returning migrants teach children English in preparation for their future migration north. ${ }^{7}$ If you or I have something to buy or sell - my surplus labor, your surplus labor, my raw materials, your automobile, my genetic inheritance, your genetically modified hybrid, this common sense view says, we'll figure out how to communicate.

But of course it's not really that simple. All markets are linguistic markets in the sense that exchanges are conducted in language. But all develop in landscapes that are always already historically, socially,

6 I thank Ondina $\mathrm{X}$ for this information

7 I thank XX Fabregas for this datum. 
affectively and symbolically organized, in which all kinds of forces are already at work. That is why the commonsense, rational view, will never be enough to explain what goes on. Human communities all have linguistic divisions of labor, language operations that are assigned to particular people and forbidden to others. Relations of difference are marked by and performed through language. The symbolic forces of language can trump pragmatism anytime. One need only consider the energy people invest I learning liturgical and scriptural languages, or name-calling murders like the one in House of Sand and Fog.

Linguistic difference acts continually as a source of what Anna Tsing calls "friction," the rough interactions through which global processes act and come into being (TSING, 2005). I have begun to suspect that the absence of a reflection on language is a condition of possibility for the knowledge-makers of globalization, a foundational silence that makes it possible for globalization to be imagined as it is being imagined. At the same time, the global languagescape is itself changing rapidly. Even the experts have no idea what the world will look like linguistically a hundred years from now. That is a truly dramatic fact.

One can take steps toward bring language out of this transparency by asking two sets of questions. First, and most obvious, in what ways is the bundle of processes denoted as globalization determining what's going on with language, and in what ways is language determining that bundle of processes called globalization? To these I add an additional question: how are these dynamics in turn determined by particular properties intrinsic to human language? That is, what do the specific characteristics of human language make possible and impossible, likely and unlikely, easy and hard? This is my way of trying to capture the agency of language in the domains of globalization. I'll 
exemplify this approach in what follows, by looking at three aspects of globalization: migration, "world" scenarios, and translingual poetics.

\section{Migrancy, redistribution and distributability}

Let me start with migration, a process universally seen as central in accounts of globalization. When people move, their languages move with them. From a linguistic point of view, then, migration can be imagined as a redistribution of linguistic competencies, something that is happening now on the planet, on an unprecedented range and scale. The news media register this constantly in anecdotes, like a recent news item reporting that the Dublin police department now needs interpreters in forty-one languages. Nothing could seem more obvious and natural than the fact that when people move, their languages move with them. But as soon as you start thinking about it, some strong and consequential constraints on this process come into view. For one thing, it's not optional. People can leave many things behind when they migrate, but language is not one of them. Nor can languages simply be exchanged or traded in on arrival the way dress, customs, even religion can. However much you might wish it, you can't convert from one language to another the way you can convert to a religion or change your diet. Try as you might, you can't get rid of a language you know by an act of volition. Languages can be forgotten only over long periods of time, and under quite narrow circumstances - and even then they can revive without one's wishing as soon as one hears them spoken. All the national language policies in the world can't make these realities go away. When people move, their languages move with them. Language is a big reason imperial and diasporic histories remain in play in the new world order.

Of course people can often (but not always) learn new languages, and this is the other large scale redistribution of competencies that 
migration brings about. Again common sense regards this as natural. In the common sense view mentioned above, language is imagined as a kind of self-regulating market. But this is seriously misleading. For there are strong constraints on how linguistic competencies are acquired, and these have major consequences. Language learning, even of one's first language, requires five things in abundance: time, effort, desire (or motivation), input, and use. For literacy, there's a sixth requirement: instruction. The distribution of linguistic competencies is determined by the degree to which these five elements are available or unavailable to people, regardless of what language rights, laws or expectations might be in play. And these elements are distributable, that is, they can be administered and regulated, made more or less available in intentioned, programmatic ways. In language policy studies we take this so thoroughly for granted it's hard to see what a dramatic fact it is. States, communities, families, institutions can encourage, impose, withhold, facilitate or impede the acquisition of linguistic competencies. And these entities often engage in fierce struggles within and between each other over language. In this sense, language acquisition is anything but spontaneous and natural. As human mobility increases, control of access to particular language competencies sustains relations of hierarchy and exploitation of many kinds. In international labor circuits, your ability to compete for jobs, and move upward in labor markets depends critically on what languages you know or don't know and how well you do or don't know them. Your socioeconomic mobility is determined by your access, or degree of access, to language learning - to those four necessary elements: time, effort, motivation, and input. All over the planet, linguistic gatekeeping - requiring language abilities without providing people the means to acquire them - keeps people "in their place," establishing permanent, renewable underclasses. Grasping the spread of global English, for instance, re- 
quires asking both who is and who is not getting access to the acquisition of English (which 300 million Chinese, for example?). The distribution of linguistic competencies is heavily gendered. The House of Sand and Fog stages the paradigm: monolingualism keeps women in the sexual contract and out of the labor market, a distribution often coded positively: women as guardians of tradition. This paradigm is a subject of intense debate among many indigenous groups today. I will never forget the fury of a Zapatista woman whom I heard give a speech, in Tzotzil, about her lack of access to education and thus to Spanish. "When we are little they tell us we are too young to go to school, when we are older they tell us it is too late to bother with education since we are about to get married." "Her remarks had to be translated by a male member of her delegation, and that infuriated her. But she insisted on making the statement. Studying a Mazahua-speaking community in central Mexico, linguist Dora Pellicer found that the women, seen as guardians of the language, were deliberately killing it off, declining to pass it on to their children, on the grounds that it would not help them get ahead. Many Americans have had parents, grandparents or great grandparents (especially Native American ones) who made similar decisions. Today many indigenous communities are engaged in excruciating debates about whether to invest in language preservation, or let their languages go.

If language learning requires an abundance of time, effort, motivation, input, and use, language loss results when some or all of those elements stop being available between the older and younger generations between whom the language must pass. That can happen only in the context of dramatic upheaval in material life. At the same time, as the examples above suggest, the mobility of languages makes them

8 Zapatista delegation to Guadalajara, Mexico, as part of the Consulta Ciudadana, March 1999. 
ungovernable. They can be appropriated, broadcast, downloaded, picked up without permission. Nobody owns languages; they can't, at least so far, be patented. In electronic form they can travel anywhere any time. Satellite TV, email, internet telephone have transformed the linguistic face of migrancy and altered the relation of migrancy to home. Indigenous languages acquire new roles in new places, sometimes precisely because their distribution is limited. When the Yucatan cartel controlled the drug trade in Central California, I'm told, Yucatec Maya became the its lingua franca. On the one hand, the language was inaccesible to the police, and on the other it established relations of trust and obligation traceable back to the source. In the1990s, the author of the only Nahuatl textbook published in the United States began receiving a string of orders from California penitentiaries. Mexican and Chicano prisoners had begun studying and using Nahuatl as an identity marker and secret code. Native Nahuatl speakers were teaching the language to fellow Mexican inmates. Tail bites dog: the prejudice that stigmatized and suppressed the hemisphere's indigenous languages for half a millenium enabled this strange and sorrowful renaissance.

To sum up, then, I'm making two points about language and migration. First, accelerated migration is producing a redistribution of linguistic competencies on an unpredecented scale, resulting in what you might call new languagescapes (following Appadurai (1996) in many parts of the globe. Second, such redistribution is possible because distributability is an inherent feature of human language. This distributability of linguistic competencies has strongly defined constraints, and these determine many of the linguistic dimensions of globalization. 


\section{World scenarios and the bias toward comprehension}

Let me move now to a second phenomenon universally identified with what is called globalization: the proliferation of planetary-scale institutions and "world" scenarios, from the World Bank to the World Social Forum to World Council of Indigenous Peoples, World Summits on water, global warming, racism, and other transnational issues. "World" scenarios involve the co-presence of dozens of linguistic systems, and are brought into being by extensive translingual operations and arrangements. These linguistic operations are so taken for granted that accounts of these scenarios seldom even mention them. In February 2005, for example, the UN convened an international meeting of animal herders (pastoralists) from twenty-three countries at a remote site in the Ethiopian desert, thirteen hours' drive from Addis Ababa. Reporting on the meeting, The New York Times quoted participants commenting on how they'd identified shared concerns. But it said almost nothing about how these rural herders, speakers of some of the world's most remote languages, communicated with one another, nor of the translingual operations that had to take place at sites all over the world in order to organize the meeting in the first place. What chains of interpretation made it possible for the Tibetans to communicate with the Aymara?

"World" scenarios depend on two familiar translinguistic mechanisms: interpretation and lingua franca. Both depend on a fundamental aspect of language that most linguistic theorizing obscures, and that is again so obvious we can't see it: language's huge bias toward comprehension. I refer to the fact that humans' ability to understand utterances in their language(s) is infinitely greater in range than their ability to produce utterances. This is why everyone can understand speakers who don't speak their language the same way they do, or who speak it partially and imperfectly. This is what is going on when some- 
one perceives someone else as "having an accent." This extraordinary elasticity of comprehension makes interpreters able to interpret, and lingua francas able to be "franca." Indeed comprehension is even involuntary in the way speech is not. A person can choose or refuse to speak, but the ability to withhold comprehension is extremely limited. People can understand fully languages that they don't speak at all.

Modern linguistics implicitly theorizes language from the point of view of production, and heuristically assumed comprehension was its mirror image, as in Saussure's famous symmetrical drawing

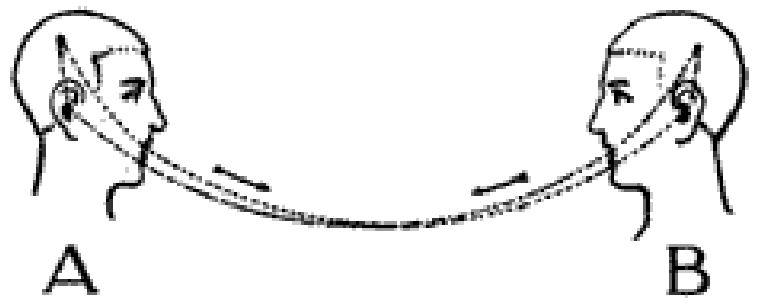

What diagram would express the asymmetry between production and comprehension?

The bias of language toward comprehension makes it possible for language to mark all kinds of differences, while maintaining comprehension across difference. Men and women can speak very differently but understand each others' utterances; people who occupy different positions in hierarchies are likely to mark their differences linguistically, but they still must comprehend each other in order to enact or challenge the hierarchy. Within languages the bias to comprehension enables new groups to mark a language as their own without endangering intelligibility with their Others. The bias towards comprehension means language can be permeated with marks of difference and incompetence, and still enact communication.

To the extent that global networks exist at all, they depend on this fact. It doesn't take a UN summit to demonstrate this point. Not 
long ago I was standing at an intersection in downtown New York City beside one of the ubiquitous corner markets that are a New York trademark. A woman's voice, with the Korean accent of the store manager, cried out 'Water!' and one of the store's Mexican employees bounded into the street in pursuit of a man who had just snatched a bottle of water. I was standing on the corner with two delivery workers, a Jamaican and a Guatemalan. The Jamaican grabbed the Mexican by the arm and gently said, 'No, mon, don't be a fool. Let him go. You could get yourself killed.' A dialogue ensued that ran something like this (with gestures, accents, the performative bleached out by writing):

Mexicano: But he stole water. It's my job.

Jamaican: No, mon, it's your job to chase him inside the store, but in the street, let him go. Don't risk your life for fifty cents.

Mexicano: If I don't stop him, the next guy will do the same thing.

Jamaican: That's not your problem, mon. you talkin' 'bout fifty cents. And not even your fifty cents.

Mexicano: It's not the money. It's the act.

Jamaican: Nobody else cares about you, mon. You don't understand the system.

Mexicano: No, YOU don't understand the system.

The Guatemalteco apparently did not speak enough English to join the debate, but he seemed to understand well enough, and listened intensely. Fascinated, I stood by thinking, 'The future of this city is being created through exchanges like these.' Every minute of every day, in public, private, and institutional spaces, the residents of the world's global cities are at work exploring and explaining differences, creating clashes and resolving them, negotiating ethics, esthetics, spa- 
ce, manners, meanings, and the assumptions of mutual responsibility that make collective life work or fail. Radical inequalities of all kinds are constitutive features of this collective life, like the global processes that produce it.

In the exchange I witnessed, comprehension is going on in multiple modes. semantically, the speakers explored their differences through a shared imaginary object, the system, about which they agreed they had different understandings. Each acknowledged the other's version, and the importance of knowing the system. You could say that the participants, including myself, created a momentary, improvised community around a shared pursuit of truth, and this succeeded without a need to reach consensus. The exchange was imperfect -- the Guatemalan, for instance, could not participate fully; the Korean store manager, stuck behind her counter, did not participate in the dialogue, and neither did the water-snatcher. The indicator of its success was one that applies all the time in social life: violence was avoided.

Performativity here was at least as important as meaning, and the two worked in opposite directions. At the level of meaning, the Jamaican argued for self-interest and self-preservation. Yet at the level of embodied practice, he was performing an act of altruism and solidarity, a fact underscored by the gentleness of his words. By his understanding of the system, the safety of the Mexicano was not his problem, yet by intervening he went out of his way to make it his problem. At the level of argument, the Mexicano disagreed with the Jamaican, but at the level of embodied practice, he de facto took the advice he purported to reject - he did stop. (The performance of the water-snatcher also entered the equation. In defiance of his act of theft, he strolled up the street, a woman on his arm.) 


\section{Extroversion and translingual poetics}

Let me turn to a third phenomenon associated with globalization, this time from the sphere of cultural expression. It's what I call translingual poetics. The novel I mentioned earlier, The House of Sand and Fog (DUBUS, 2000) provides an example. The novel has several narrators, one of whom is an Iranian immigrant who is speaking and thinking most of the time in Farsi. The novel is written in English. Dubus worked for two years with a Farsi teacher in order to invent a fictional English simulacrum of his character's native speech and thought. Here is an excerpt:

Nadi is near the sink preparing the samovar for later and she calls out in Farsi for Esmail to take off his shoes, and then come into the kitchen for washing. She regards me, her hands upon the samovar lid, and she motions with her head for me to commence explaining. Esmail removes his shoes, asks me if the automobile in the driveway does not belong to that woman, Bawbaw-jahn. Again I am faced with the moment of not knowing how much of our situation to share with $\mathrm{m}$ son. But then I tell to myself it is his situation as well (p. 251).

The reader grasps this translinguistic graft with no difficulty. We understand the sentences, also comprehend effortlessly that the author intends us to recognize that the character thinking and narrating here is not a native speaker of English. How is this possible?

Dubus's creation is an instance of what I call translingual poetics, whose proliferation today I take to be another linguistic dimension of globalization. I use this term to refer specifically to texts or performances where more than one linguistic system is operating at the same time. On the reception end the effect is the one discussed earlier: Dubus, you could say, is writing with an accent. For bilingual readers, such writing often produces the experience of reading one language and hearing another, an experience familiar to readers of US Latino literature. 
In a new and fascinating book about the history of Spanish in the Philippines, Vicente Rafael offers an approach to these operations. He speaks of texts in which one linguistic system is used to "host" another - English would be said to be hosting Farsi in Dubus's novel (RAFAEL, 2005). In the bilingual title of H.G. Carrillo's 2004 novel Loosing My Espanish, English hosts elements of Spanish phonology the obligatory $e$ before $s$ at the beginning of a word; the absence of the $z$ sound, eradicating the distinction between "loosing" and "losing" and thereby producing a pun in English. But the pun is only there if you recognize the co-presence of the Spanish and English phonological elements. The two languages can't be disentangled here.

Artistic practices in which linguistic hosting or grafting becomes a distinctive esthetic value are not a new phenomenon, but their proliferation over the last decade is, I believe, new. In film and television it has become common for works to use multiple languages accompanied by subtitles, or not (examples include the Stephen Spielberg's "Munich" (2005), George Clooney's "Syriana" (2005), Alejandro González Iñarrítu's "Babel" (2006) and Manoel de Oliveira's "Um filme falado" (2003). In the United States, bilingual radio finally burst forth around the year 2000, actively celebrating code-switching virtuosity in a variety of languages. A second well-known development is hip hop, a poetic-musical form that despite a rhythmic formula based in English prosody and African American English vernacular, has hip hopped into languages all over the world. In languages other than English, hip hop singers reorganize the prosody and stress structures of their languages to host the imported form, and this rhythmic transgression itself often carries the rebellious class and generational message that drives the hip hop genre. Often, hip hop values multilingualism, as in Bolivian forms that combine Spanish, Aymara and Portuguese. PLAY SAMPLE

That idea of one language hosting another points toward a third feature of human language that drives the global languagescape: its 
extroversion. Language has an outward disposition to seize elements from other systems with which it comes in contact; languages are actively open, even attracted to otherness. This active openness of linguistic systems makes language uncontainable and transgressive (this is not the way linguists are trained to think about it). It means for example that language policies and policing mechanisms can never control what people actually do linguistically. Like Nahuatl in the prisons, language is always able to dance around, jump over or seep through barriers set to circumscribe its functions. This fact is a tremendous challenge to theory. In fact taking such matters off the theoretical table was the main purpose for building modern $1 \mathrm{x}$ theory around the langue/parole, competence/ performance dichotomy.

Where there are boundaries, language will cross them. This extroverted dynamic is the creative engine of the translingual poetic practices that I've been alluding to, and of all kinds of contemporary virtuosities like bilingual radio and multilingual email and text-messaging styles. It also plays a role in geopolitics. Not long ago someone forwarded me an email from a former foreign service officer commenting on a recent treaty on nuclear power between North Korea and the US. The two countries he said, had agreed to substantively different things - what the terms of the treaty meant geopolitically were different in the Korean and English versions. And these differences, he underscored, were what had made it possible for both sides to sign the agreement. Here, notice, we're not dealing with originals and translations, but with a document produced simultaneously in multiple languages, with no original whose authority can be called upon to decide differences. Lubricated by language, the space between the two versions is the space of geopolitics. 


\section{Normativity and Theory}

Modern linguistics was founded on a commitment to descriptive as opposed to prescriptive approaches to language, that is, to studying how people speak rather than telling them how they ought to speak. Grasping the agency of language in global processes, however, requires normativity, grounds on which to foster some scenarios over others. Can linguistics be normative without being prescriptive? What kind of an account should linguistic theory give of language's powers to inflict violence, cause suffering, deceive and abuse? Theory is powerful. Should it aim to construct a grammar that accounts for these capacities in the same terms by which it accounts for everything else language does? (In which case, for instance, lying and truthtelling are structural equivalents in the system.) Or should language's powers of violence be theorized as violations and perversions of language, in which case the theory reproduces norms internal to language itself? As I argued some years ago (PRATT, 1987), linguists have for the most part sidestepped this question by constructing theories that are explicitly non normative and implicitly normative, that naturalize norms about speakers, speech communities, exchanges as cooperative, and so on. In fact, as I have argued elsewhere, linguistic theory and free market ideology share two unacknowledged assumptions: (a) a concept of exchange that falsely reads equivalence as equality, and (b) a concept of self-regulation that falsely reads equivalence as equity. As I hope to elaborate in our conversations in Oaxaca, approaches to language through ecological thought and through the concept of intangible heritage hold the possibility of normative approaches to language that are not articulated through an externally driven ethics but that are predicated on the specific faculties of language itself. 
Muiraquitã, PPGLI-UFAC, v.2, n.1, Jul/Dez, 2013

LIINGUASQUE VIAJAM: EM DIREÇÃO AUMAIMAGINAÇÃO GEOLINGUÍSTICA ABSTRACT

In a close dialogue with questions related to the understanding of linguistic dimensions which are featured around the planetary, social, ecological, economic, political, and imaginary realignments driven by contemporary globalization, this article is focused on the role and importance of language in terms of defining and even determining the processes and transformations wrought by this globalization. It especially takes into account the need to put the language in the center of this debate, as an important category of analysis for thinking about the dynamics of the ongoing transformations.

KEYWORDS: Globalization. Migration. Geolinguistics. Language. Linguistic competence.

\section{REFERENCES}

APPADURAI, A. Modernity at Large. Minneapolis: University of Minnesota Press 1996.

CARRILLO, H.G. Loosing My Espanish. New York: Pantheon 2004.

DUBUS, A. The House of Sand and Fog. New York: Vintage 2000.

HORNBLOWER, M. "Putting Tongues in Check", SIRS Researcher. Winter 1997, 4-5.

"THE HOUSE OF SAND AND FOG", film directed by Vadim Perelman, based on the novel by Andre Dubus III, 2003.

HOSSEINI, K. The Kite Runner. New York and London: Penguin 2003. LAIPSON, E. National Briefing on Language and National Security, sponsored by the National Foreign Language Center and the National Security Education Program, 01/16/02, www.nflc.org/security/transcript .

PRATT, Mary Louise. "Linguistic Utopias", In: Derek Attridge et al, eds., The Linguistics of Writing. Manchester: Manchester UP: 48-66. RAFAEL, V. The Promise of the Foreign: Nationalism and the Technics of Translation in the Philippines. Durham: Duke University Press 2006. SCHEMO, D. "Washington cites shortage of Linguists...", New York Times 4.16.00, A1.

TAFOLLA, C. "La Malinche," Canto al pueblo. San Antonio: Penca 
Muiraquitã, PPGLI-UFAC, v.2, n.1, Jul/Dez, 2013

Books, 1978.

TSING, A. Friction: Toward an Anthropology of Global Connection. Princeton: Princeton UP 2005. 